\title{
PENGARUH MODEL PEMBELAJARAN BERBASIS MASALAH TERHADAP HASIL BELAJAR SISWA PADA MATERI POKOK GERAK LURUS KELAS X SEMESTER I SMA NEGERI 11 MEDAN T.A. 2014/2015
}

\author{
Nurliana dan Rita Juliani \\ nurlia_ana@yahoo.co.id \\ Jurusan Fisika FMIPA Universitas Negeri Medan \\ Jalan Willem Iskandar Pasar V Medan, 20221
}

\begin{abstract}
This study aims to determine the effect of problem-based learning model for student learning outcomes in the subject matter straight motion $\mathrm{X}$ class first semester of SMA 11 Medan T.A. 2014/2015. This research is quasi experiment. The population is the entire class X MIA semester SMA 11 Medan consists of five classes. Samples were taken two classes of grade X MIA 3 as the experimental class and class X MIA 4 as the control class, each of which consist of 40 students is determined by cluster random sampling. Both classes are given different treatment, the experimental class with problem-based learning model and grade control with conventional learning. The data used in the research is a description of the number of about 10 items that have been divalidkan. The results showed that the learning outcomes of students using problem-based learning model has increased significantly. Testing results of the study by testing the hypothesis of effect is obtained that the problem-based learning model for student learning outcomes in the subject matter straight motion X class first semester of SMA 11 Medan T.A. 2014/2015.
\end{abstract}

Keywords : problem-based learning, straight motion, student learning outcomes

\section{PENDAHULUAN}

Pendidikan merupakan salah satu komponen penting dalam meningkatkan kualitas sumber daya manusia. Pengembangan kualitas sumber daya manusia menjadi suatu keharusan yang diemban pendidikan formal dalam memasuki era globalisasi. Namun, salah satu masalah yang dihadapi dunia pendidikan di Indonesia adalah masalah lemahnya proses pembelajaran. Proses pembelajaran yang diterapkan lebih diarahkan pada kemampuan untuk menghafal informasi, siswa kurang didorong untuk mengembangkan kemampuan berpikirnya. "Kebiasaan menghafal informasi tentunya merupakan hasil kondisi pembelajaran yang masih bersifat konvensional dan tidak menyentuh ranah dimensi peserta didik itu sendiri. Secara substansial, proses pembelajaran hingga kini masih didominasi oleh guru dan tidak memberikan akses bagi anak didik untuk berkembang secara mandiri melalui penemuan dalam 
proses berpikirnya" (Trianto, 2009:5).

Proses pembelajaran Ilmu Pengetahuan Alam, khususnya fisika pada umumnya masih didominasi oleh guru. Guru sering menjadikan siswa sebagai objek belajar bukan sebagai subjek belajar, siswa tampak pasif dan menerima pengetahuan sesuai dengan yang diberikan guru. Proses belajar mengajar yang dilakukan di sekolah masih berpusat pada guru (teacher centered). Guru menyajikan materi fisika dalam bentuk rumus- rumus dan perhitungan, sehingga banyak siswa yang kurang menyukai pelajaran fisika karena menganggap belajar fisika sulit, tidak menarik dan membosankan.

Proses pembelajaran yang masih didominasi oleh guru tarlihat dari hasil observasi awal yang telah penulis lakukan di SMA Negeri 11 Medan dengan menggunakan instrumen angket dan wawancara, diperoleh sejumlah data dari 37 siswa kelas X, 91,9\% menyatakan bahwa proses belajar mengajar yang dilakukan di sekolah masih berpusat pada guru. Guru hanya menjelaskan materi kemudian memberikan latihan soal. Siswa kurang dibimbing untuk melakukan percobaan atau eksperimen dari materi yang telah dijelaskan oleh guru. Laboratorium di sekolah sebenarnya sudah ada, akan tetapi kurang diperdayakan, sehingga pengetahuan yang diperoleh siswa di sekolah sebatas dari buku dan materi yang disampaikan guru melalui metode ceramah serta pemberian latihan soal. Minat siswa terhadap pelajaran fisika masih tergolong rendah. Hasil observasi menunjukkan bahwa $86,5 \%$ siswa kurang termotivasi untuk bertanya saat proses pembelajaran fisika berlangsung, bahkan ada 12 orang siswa yang tidak pernah bertanya.

Berdasarkan

hasil

wawancara dengan salah satu guru bidang studi fisika di SMA Negeri 11 Medan, diketahui bahwa hanya 25\% siswa yang menyukai pelajaran fisika. Salah satu faktor penyebabnya karena proses belajar mengajar yang dilaksanakan masih berpusat pada guru dan masih menggunakan pembelajaran konvensional.

Salah satu pembenahan proses belajar mengajar fisika yang dilakukan adalah penerapan model pembelajaran kreatif, aplikatif dan menyenangkan, sehingga siswa mudah memahami dan menguasai konsep fisika dan menerapkannya dalam kehidupan sehari-hari. Pemilihan model yang tepat untuk setiap konsep membuat tujuan proses hasil belajar mengajar yang sudah ditentukan tercapai dengan baik.

Salah satu alternatif yang dapat digunakan untuk mengatasi kesulitan tersebut adalah dengan menciptakan suasana pembelajaran yang langsung berhubungan dengan kehidupan sehari-hari dan dapat menyampaikan berbagai konsep yang diajarkan, sehingga siswa dapat menggunakan dan mengingat lebih lama konsep tersebut. Model pembelajaran berbasis masalah adalah salah satu upaya solusinya, model pembelajaran berbasis masalah dirancang dengan tujuan untuk membantu siswa mengembangkan kemampuan berfikir dan mengembangkan 
kemampuan dalam memecahkan masalah kehidupan sehari-hari.

Model pembelajaran berbasis masalah merupakan suatu model pembelajaran yang didasarkan pada permasalahan yang membutuhkan penyelidikan autentik yakni penyelidikan yang membutuhkan penyelesaian nyata dari permasalahan nyata, sehingga memungkinkan siswa memahami konsep fisika bukan sekedar menghafal konsep (Trianto, 2009:90). Menurut Arends (2008:4), esensi pembelajaran berbasis masalah berupa menyuguhkan berbagai situasi bermasalah yang autentik dan bermakna kepada siswa, yang berfungsi sebagai landasan investigasi dan penyelidikan siswa. Dengan kata lain, dapat dikatakan bahwa model pembelajaran berbasis masalah bukan hanya sekedar model pembelajaran yang diarahkan agar peserta didik dapat mengingat dan memahami berbagai data, fakta atau konsep, akan tetapi bagaimana data, fakta, dan konsep tersebut dapat dijadikan sebagai alat untuk melatih kemampuan berpikir siswa dalam menghadapi dan memecahkan suatu persoalan.

Berdasarkan uraian diatas, penulis berkeinginan melakukan suatu penelitian untuk mengetahui pengaruh model pembelajaran berbasis masalah

terhadap hasil belajar siswa pada materi pokok gerak lurus kelas $\mathrm{X}$ semester I di SMA Negeri 11 Medan.

\section{METODE PENELITIAN}

Penelitian dilaksanakan di SMA Negeri 11 Medan Jalan Pertiwi
No.93 Kecamatan Medan Tembung dan pelaksanaan pada bulan September 2014 semester ganjil T.A. 2014/2015.

Populasi dalam penelitian adalah siswa kelas X MIA yang terdiri dari lima kelas. Sampel diambil dengan cluster random sampling dan diperoleh kelas eksperimen adalah kelas X MIA 3 dan kelas kontrol adalah kelas $\mathrm{X}$ MIA 4.

Penelitian melibatkan dua kelas yang diberi perlakuan yang berbeda. Satu kelas dijadikan kelas eksperimen dengan menggunakan model pembelajaran berbasis masalah dan kelas lainnya dijadikan kelas kontrol dengan menggunakan pembelajaran konvensional. Desain penelitian dapat dilihat pada Tabel 1.

Tabel 1. Two Group Pretest-Postest Design

\begin{tabular}{|c|c|c|c|}
\hline Kelas & Pretes & Perlakuan & Postes \\
\hline Eksperimen & $\mathrm{T}$ & $\mathrm{X}_{1}$ & $\mathrm{~T}$ \\
\hline Kontrol & $\mathrm{T}$ & $\mathrm{X}_{2}$ & $\mathrm{~T}$ \\
\hline \multicolumn{3}{|c}{ (Arikunto, 2010) }
\end{tabular}

Keterangan :

$\mathrm{T}=$ Pretes dan Postes diberikan kepada kelas eksperimen dan kelas kontrol.

$\mathrm{X}_{1}=$ Pembelajaran dengan menerapkan model pembelajaran berbasis masalah $\mathrm{X}_{2}=$ Pembelajaran dengan menerapkan pembelajaran konvensional

Peneliti memberikan pretes kepada kelas eksperimen dan kelas kontrol. Instrumen yang digunakan adalah tes hasil belajar 
siswa berbentuk uraian sebanyak 10 soal. Tes hasil belajar terlebih dahulu distandarisasi dengan menggunakan uji validitas. Data pretes yang diperoleh kemudian dianalisis dengan uji normalitas menggunakan uji chi-kuadrat dan uji homogenitas menggunakan uji kesamaan varians. Setelah itu dilakukan pengujian hipotesis dua pihak untuk mengetahui kemampuan awal siswa pada kedua kelompok sampel, dalam hal ini kemampuan awal kedua sampel tersebut harus sama. Selanjutnya peneliti mengajarkan materi pelajaran dengan menggunakan model pembelajaran berbasis masalah pada kelas eksperimen dan pembelajaran konvensional pada kelas kontrol. Cara untuk mengetahui perbedaan hasil akhirnya maka dilakukan postes kemudian data postes dianalisis dengan menggunakan uji hipotesis satu pihak untuk mengetahui pengaruh perlakuan model pembelajaran berbasis masalah terhadap hasil belajar siswa.

\section{HASIL DAN PEMBAHASAN Hasil Penelitian}

Data yang dideskripsikan pada penelitian meliputi data hasil belajar siswa pada materi pokok gerak lurus yang diberikan pada kedua sampel dengan perlakuan berbeda yaitu kelas eksperimen menggunakan pembelajaran berbasis masalah dan kelas kontrol menggunakan pembelajaran konvensional. Bentuk pretes dan postes yang digunakan dalam penelitian berupa uraian dengan jumlah soal 10 item yang telah divalidkan. Data nilai pretes kelas eksperimen dan kelas kontrol ditunjukkan pada Gambar 1.

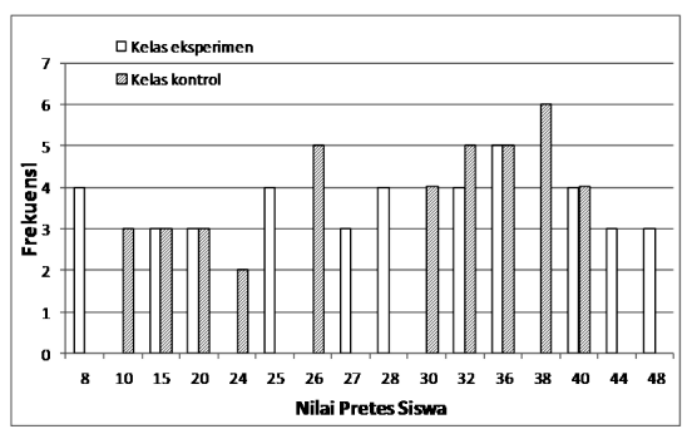

Gambar 1. Diagram batang nilai pretes siswa.

Diagram batang menunjukkan nilai pretes pada kelas eksperimen dan kelas kontrol dengan perbandingan rata-rata nilainya adalah 29,35 dan 29,03. Data nilai postes kelas eksperimen dan kelas kontrol ditunjukkan pada Gambar 2.

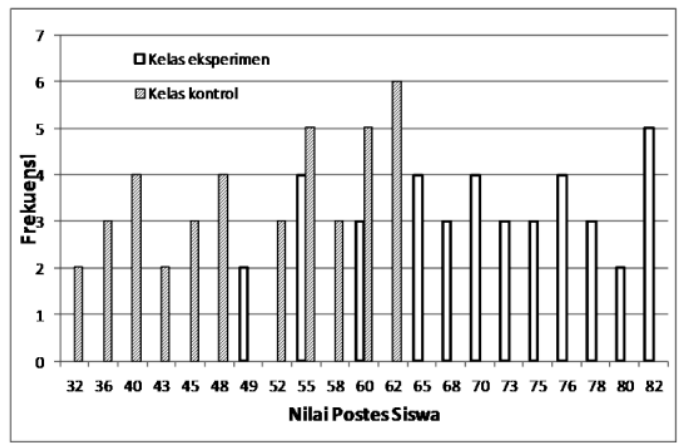

Gambar 2. Diagram batang nilai postes siswa

Gambar 2. menunjukkan bahwa nilai postes kelas eksperimen lebih tinggi dari pada nilai postes kelas kontrol, perbandingan ratarata nilainya adalah 69,85 dan 50,55. Terdapat peningkatan hasil belajar yang diperoleh pada kedua kelas tersebut. Dengan demikian hasil belajar siswa kelas eksperimen lebih baik dibandingkan dengan hasil belajar siswa kelas kontrol. 
Hasil penelitian menunjukkan bahwa peningkatan hasil belajar siswa didukung oleh aktivitas siswa dalam proses pembelajaran. Aktivitas yang diamati dalam penelitian adalah mengeluarkan pendapat, diskusi, berani dan memecahkan soal. Keterkaitan hasil belajar dengan aktivitas siswa ditunjukkan dari peningkatan nilai rata-rata aktivitas siswa kelas eksperimen pada setiap pertemuan dengan nilai rata-rata pada pertemuan pertama yaitu $52,71 \%$, pertemuan kedua yaitu $62,08 \%$ dan pada pertemuan ketiga yaitu $70,21 \%$, sehingga diperoleh nilai rata-rata aktivitas siswa selama tiga pertemuan yaitu $61,67 \%$. Nilai ratarata aktivitas siswa kelas eksperimen divisualisasikan oleh diagram batang pada Gambar 3 .

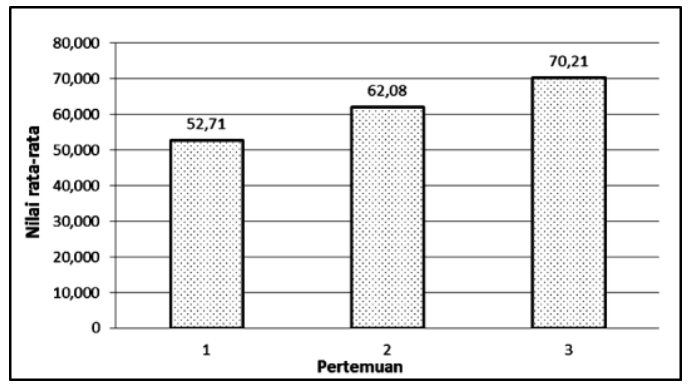

Gambar 3. Diagram batang nilai aktivitas siswa kelas eksperimen

Peningkatan hasil belajar siswa tidak hanya didukung oleh aktivitas siswa, tetapi juga didukung oleh keterampilan siswa dalam proses pembelajaran. Keterampilan yang diamati dalam penelitian adalah mempersiapkan alat dan bahan, merancang percobaan, dan pengamatan. Hasil pengamatan menunjukkan adanya peningkatan nilai rata-rata keterampilan siswa kelas eksperimen pada setiap pertemuan dengan nilai rata-rata pada pertemuan pertama yaitu $55,28 \%$, pertemuan kedua yaitu $62,22 \%$ dan pada pertemuan ketiga yaitu 70,56\%, sehingga diperoleh nilai rata-rata keterampilan siswa selama tiga pertemuan pada kelas eksperimen yaitu 62,69\%. Peningkatan nilai rata-rata keterampilan siswa kelas eksperimen divisualisasikan oleh diagram batang pada Gambar 4 .

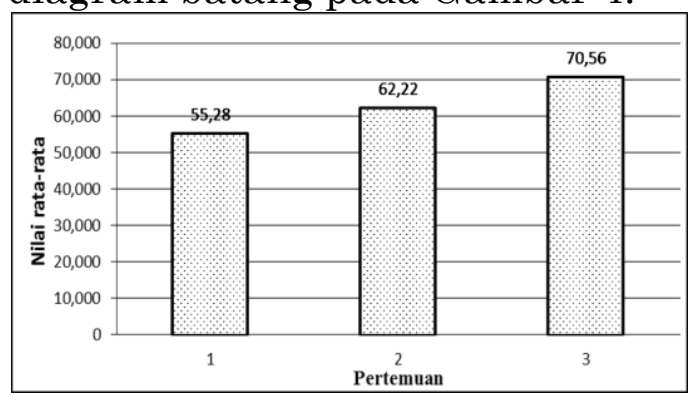

Gambar 4. Diagram batang nilai keterampilan siswa kelas eksperimen.

\section{Pembahasan}

Berdasarkan data penelitian dapat dilihat bahwa kelas eksperimen yang diajar dengan menggunakan model pembelajaran berbasis masalah diperoleh hasil nilai rata-rata pretesnya 29,35 dan nilai rata-rata postes yaitu 69,85 , sedangkan pada kelas kontrol yang diajar dengan menggunakan pembelajaran konvensional diperoleh hasil nilai rata-rata pretesnya 29,03 dan nilai rata-rata postes yaitu 50,55. Hasil penelitian menunjukkan bahwa ada pengaruh model pembelajaran berbasis masalah terhadap hasil belajar siswa pada materi pokok gerak lurus di SMA Negeri 11 Medan.

Hasil penelitian menunjukkan bahwa peningkatan hasil belajar didukung oleh aktivitas dan keterampilan siswa dalam proses pembelajaran. Hal ini disebabkan 
karena pada saat proses belajar mengajar dengan menggunakan model pembelajaran berbasis masalah siswa dilibatkan secara aktif dalam proses pembelajaran. Siswa dituntut untuk mengembangkan kemampuan berpikir ketika disajikan suatu permasalahan dan adanya interaksi yang terjadi antar siswa maupun antara siswa dengan guru yang melatih kemampuan berkomunikasi, seperti yang terlihat ketika diskusi di kelas terjadi interaksi tanya jawab dan siswa bebas mengeluarkan pendapatnya masingmasing. Siswa dilatih untuk lebih mandiri dan mengembangkan kemampuan berpikir khususnya kemampuan problem solving siswa yang terlihat ketika siswa melakukan eksperimen yang dimulai dari tahap merancang percobaan, pengamatan, dan menganalisis data yang diperoleh, sehingga penguasaan terhadap materi pelajaran dapat lebih dalam dan membekas lama. Pendapat Arends (2008:41), bahwa esensi pembelajaran berbasis masalah berupa menyuguhkan berbagai situasi bermasalah yang autentik dan bermakna kepada siswa sehingga dapat membantu siswa untuk mengembangkan keterampilan berpikir dan keterampilan mengatasi masalah, mempelajari peran-peran orang dewasa dan menjadi pelajar yang mandiri. Penerapan pembelajaran berbasis masalah dapat mendorong siswa untuk melakukan dialog bersama untuk mengembangkan keterampilan berpikir dan keterampilan sosial.
Peneliti sebelumnya dilakukan oleh Hasibuan (2009). Hasil penelitian menunjukkan bahwa nilai rata-rata postes kelas ekperimen menggunakan model pembelajaran berbasis masalah lebih tinggi dibanding kelas kontrol menggunakan pembelajaran konvensional dengan nilai rata-rata postes pada kelas eksperimen adalah 7,54 dan kelas kontrol adalah 6,55. Hasil belajar siswa kelas eksperimen mengalami peningkatan dengan nilai pretes yaitu 4,32 meningkat menjadi 7,54 pada hasil postes. Peningkatan hasil belajar siswa kelas eksperimen didukung oleh adanya peningkatan nilai aktivitas siswa pada setiap seri kegiatan yang dilakukan dengan nilai rata-rata pada pertemuan I $43,33 \%$ dengan kategori kurang baik, pada pertemuan II meningkat menjadi $78,67 \%$ dengan kategori baik, sehingga hasil penelitian Hasibuan (2009) menyimpulkan bahwa dengan model pembelajaran berbasis masalah hasil belajar dan aktivitas belajar siswa mengalami peningkatan. Fauzi (2012) mengemukakan bahwa peningkatan hasil belajar siswa pada kelas eksperimen menggunakan model pembelajaran berbasis masalah dengan nilai rata-rata pretes 35,29 meningkat menjadi 60,43 pada hasil postes didukung oleh adanya peningkatan keterampilan siswa pada setiap pertemuan dengan nilai rata-rata pada pertemuan pertama sebesar 67,88 dengan kategori baik dan pada pertemuan kedua sebesar 80,00 dengan kategori baik. Menurut Fauzi (2012), model pembelajaran berbasis masalah merujuk pada keaktifan siswa untuk bereksplorasi 
mengumpulkan dan menganalisis data untuk memecahkan masalah, sehingga dalam proses pembelajaran berbasis masalah, siswa tidak hanya berperan sebagai penerima pelajaran melalui penjelasan guru secara verbal. Hasil penelitian yang diperoleh tentu tidak terlepas dari peran guru dalam proses pembelajaran.

Cara yang dilakukan peneliti dalam kegiatan belajar menggunakan model pembelajaran berbasis masalah dengan mengikuti tahap-tahap yang bermula dari tahap orientasi siswa pada masalah (pertama), peneliti memotivasi siswa dan memfokuskan perhatian siswa. Pada tahap mengorganisasikan siswa untuk meneliti (kedua), peneliti membantu siswa mengorganisasikan tugas-tugas belajar terkait dengan permasalahan kemudian membagikan siswa ke dalam kelompok-kelompok belajar. Tahap penyelidikan individual maupun kelompok (ketiga), peneliti membagikan LKS untuk siswa sebagai pedoman dan membimbing siswa melakukan percobaan. Pada tahap mengembangkan dan mempresentasikan artefak dan exhibit (keempat), peneliti membantu setiap kelompok menyelesaikan dan menjawab semua permasalahan yang ada serta mempersentasikan hasil diskusi kelompok yang telah disiapkan, kemudian kelompok yang lain diberikan kesempatan memberikan pendapat. Pada tahap menganalisis dan mengevaluasi proses mengatasi masalah (kelima), peneliti membantu siswa dalam mengkaji ulang pemecahan masalah sesuai dengan tujuan pembelajaran dan memberikan penguatan pada pemecahan masalah dan pada tahap ini peneliti membuat tes evaluasi untuk mengetahui pemahaman siswa.

Hasil penelitian menunjukkan bahwa penerapan model pembelajaran berbasis masalah meningkatkan hasil belajar, aktivitas dan keterampilan siswa. Hasil penelitian yang diperoleh belum maksimal disebabkan karena sulitnya menentukan masalah pada Lembar Kerja Siswa yang akan dipecahkan oleh siswa saat proses pembelajaran. Penyajian masalah merupakan hal yang sangat penting dalam penerapan model pembelajaran berbasis masalah. Keterbatasan peneliti dalam menentukan masalah yang menyebabkan hasil penelitian belum maksimal, selain itu kurangnya pengalaman peneliti dalam mengelola kelas sehingga kondisi siswa yang ribut menyebabkan penelitian menjadi kurang efisien.

\section{KESIMPULAN DAN SARAN Kesimpulan}

Kesimpulan didasarkan pada data-data hasil penelitian, sistematika sajiannya dilakukan dengan memperhatikan tujuan penelitian yang telah dirumuskan. Maka kesimpulan yang diperoleh yaitu (1) Hasil belajar siswa yang diterapkan dengan menggunakan model pembelajaran berbasis masalah lebih tinggi dibanding dengan menggunakan pembelajaran konvensional. (2) Ada pengaruh model pembelajaran berbasis masalah terhadap hasil belajar siswa pada materi pokok gerak lurus 
kelas X semester I di SMA Negeri 11 Medan T.A. 2014/2015.

\section{Saran}

Berdasarkan hasil penelitian dan kesimpulan yang menunjukkan pengaruh model pembelajaran berbasis masalah lebih baik karena adanya beberapa keunggulan model pembelajaran berbasis masalah, maka sebagai tindak lanjut dari penelitian ini disarankan beberapa hal sebagai berikut: (1) Sebelum model pembelajaran berbasis masalah diterapkan, sebaiknya mempertimbangkan materi pelajarannya. (2) Belajar untuk bisa mengelola kelas dengan baik sehingga kegiatan pembelajaran dapat terlaksana dengan efektif dan efisien.

\section{DAFTAR PUSTAKA}

Arends, R.I., (2008), Learning To Teach Edisi Ketujuh, Penerbit Pustaka Pelajar, Yogyakarta.

Arikunto, S., (2010), Prosedur Penelitian, Penerbit Rineka Cipta, Jakarta.

Fauzi, A., (2012), Pengaruh Model Pembelajaran Berbasis Masalah Terhadap Hasil Belajar Siswa Pada Materi Pokok Listrik Dinamis Kelas IX SMP N 5 Pematang Siantar T.P 2012/2013., Skripsi, FMIPA, Unimed, Medan.

Hasibuan, Y., (2009), Pengaruh Model Pembelajaran Berdasarkan Masalah Terhadap Hasil Belajar Fisika Siswa Pada Materi Pokok Gerak Lurus Di Kelas X SMA Negeri 3 Medan T.A 2009/2010., Skripsi, FMIPA, Unimed, Medan.
Trianto, (2009), Mendesain Model Pembelajaran InovatifProgresif, Kencana, Jakarta 